\title{
賀茂別雷神社の役大工と儀式における祝儀について YAKU-DAIKU AND PRESENTS AFTER CEREMONIES AT KAMOWAKEIKAZUCHI SHRINE
}

\author{
中西大輔*, 日向 進** \\ Daisuke NAKANISHI and Susumu HYUGA
}

\begin{abstract}
This paper discusses how more presents the Yaku-daiku were given after a ceremony. The Yaku-daiku were carpenters working at Kamowakeikazuchi Shrine. They were divided into two groups, and broken down into three levels. The highest level was Daiku, followed by Toryo, and Cho. Their presents showed the following three points:

1. They were given presents based on their position.

2. Carpenters in the main group were given more presents than those in the assistant group

3. They were also given what they had used during a ceremony.

These differences were related to both their ceremonial procedures and their position.
\end{abstract}

Keywords: Kamowakeikazuchi Shrine, Carpenter, Ceremony, Reconstruction, Presents given to carpenters after a ceremony 賀茂別雷神社，建築工匠，儀式，造営，祝儀

\section{1. はじめに}

江戸時代の賀茂別雷神社では、役大工と呼ばれる建築工匠たちが 建物の新造・修理を行なっていた。この役大工は正・権の 2 グルー プに分かれ、それぞれが大工・棟梁・長という階層組織をもっていた。 役大工は 9 人であり、内訳は正大工 1 人、権大工 1 人、正棟梁 1 人、

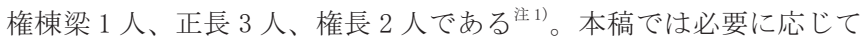
長を儀式における役割の順に正長 $a$ 、正長 $b$ 、正長 $c$ 、権長 $a$ 、権長 $b$ として区別することにする。

これまでに、役大工は江戸時代の賀茂別雷神社で造営に携わって きたことが知られている注2)。江戸時代の造営は幕府によるものであ り、寛永・延宝・正徳・寛保・安永・享和・天保・文久の 8 度実施 されている。造営に参加する諸職人は入札によって選ばれたが、本 殿など一部の建物における新造には、入札ではなく、きまって役大 工が選ばれてきた。

この役大工に関して、儀式の内容という面から検討したことがあ

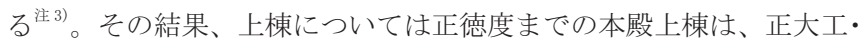
正棟梁・正長（以下、正大工のグループ）だけが執り行い、寛保度 以降も正大工のグループが主導的な役割を担っていた。これに対し て、正徳度までの権殿上棟は、権大工のグループだけが行ない、寛 保度以降も権大工のグループが主導的な役割を担っていたことがわ
かった。また木造始めでも、延宝度以前には役大工が地位の順番に 作法を行なうという形式であったものが、正徳度以降には正大工の グループと権大工のグループが順番に作法をするという形式に改め られていたことがわかった。同様に立柱・玉橋渡始めでも少なくと も寛保度以降、正大工のグループと権大工のグループが順番に作法 を行なうという形式がとられていたことがわかった。

本稿では、江戸時代に役大工が執り行った儀式について、儀式後 に渡された祝儀という面から検討する。地位と役割、祝儀の関係を みることで役大工の地位について考えたい。なお、本稿では祝儀を (1)反物や折紙、米による禄と、(2)儀式に用いられた道具、(3)儀式の ために供えられた供物、にわけて考える。

扱う儀式は木造始め、立柱、上棟、玉橋渡始めであり、前回と同 様である。本稿でいう木造始めは造営において最初の段階で行なわ れるものを指すこととする。木造始めは釿始めとも呼ばれ、事実寛 永度の造営などでは「釿始」とされているが、これも木造始めとし て統一寸る。立柱・上棟は本殿之権殿で行なわれたもののみを扱う 寛永度を除いて摂社・末社は修理のみであり、これらの儀式が行な われていないためである。玉橋渡始めとは玉橋の修理が完了したと きに行なわれる儀式のことである。なお、玉橋は本殿・権殿を画す る区域の入口である楼門の前にある。
* 京都工芸繊維大学大学院 大学院生

** 京都工芸繊維大学工芸科学研究科 教授·工博
Graduate Student, Kyoto Institute of Technology

Prof., Kyoto Institute of Technology, Dr. Eng. 
以上 4 つの儀式について、造営に関して賀茂別雷神社で作成され た日記（以下、本文中では『造営日記』）を調查した注4)。ただし、寛 永度・延宝度には『造営日記』が残っていない。そのため、寛永度 には『寛永造替遷宮記 上』(III-23-1)、『寛永造営遷宮記』(IV - A43）と題される後世の写本（これも本文中では『造営日記』とする） を用い注5)、延宝度には『造営日記』と同様、賀茂別雷神社で作成さ れた日次記（以下『日次記』）を用いることにする注6)

\section{2. 祝儀}

\section{1. 木造始め}

木造始めにおける役大工の祝儀は大工と棟梁・長の間で差がつけ られている (表 1)。寛永度の詳細は不明であるが、延宝度には正大工・ 権大工が小袖の折紙をもらい、棟梁・長は絹の折紙をもらっている。 小袖は「大正初期ごろまで絹布の綿入の着物」のことを指し、木綿 の綿入とは区別されていたといらから衤8)、大工が小袖の完成品の折 紙をもらったのに対して棟梁・長はその材料の折紙をもらったとい

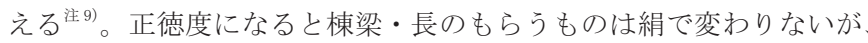
大工は金襴巻物の裂をもらっている。ともに反物ではあるが、金襴 は絹より手が込んでいる。寛保度には大工が絹 1 反をもらい、棟梁・ 長は素目録をもらっている。安永度・享和度には具体的な記述がない。 しかし、天保度・文久度には大工が絹、棟梁・長が絹 1 㱜の折紙を もらっていることから寛保度と近い形式とみることができ、安永度・ 享和度にも同種の形式が用いられていた可能性が高い。

これは禄をもらう場所と方法に関係があると考えられる。『造営日 記』の小袖や反物をもらう場面は次のように記されている注 10)。

表 1 木造始めの祝儀注 7)

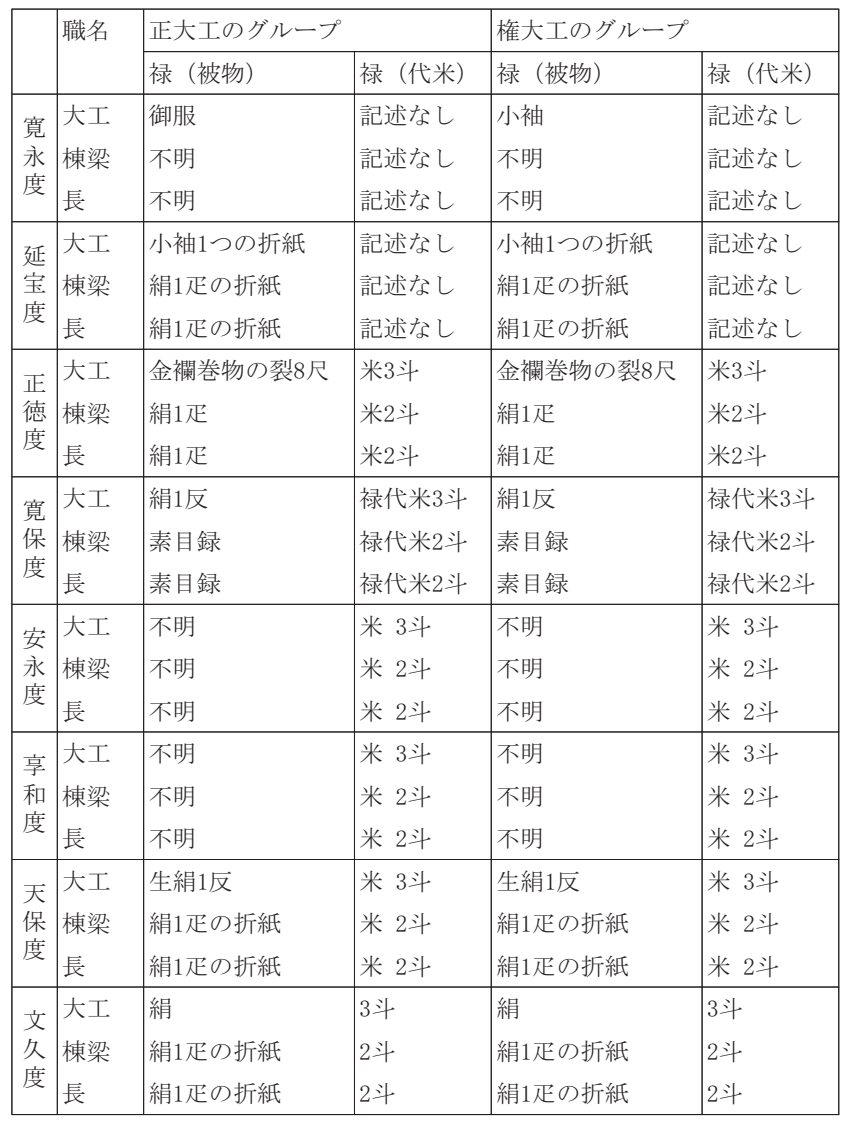

表記・単位は史料通り
次賜禄於正大工

其儀別当大夫自直会所持出、氏神祢宜二渡、氏神祢宜唐戸上 り出、請取之、於唐戸前、賜正大工左ノ肩二打掛、正大工帱受、 向唐戸、祠官一御礼、蹲踞而退キ、東二而作所二向二嗱踞、

了而退ク、次権大工二給、其義正大工二同シ、但氏神祝より 被渡之（略）

別当大夫 - 作所奉行并番匠以下着庁屋、於此所棟梁以下に禄 給別当设之作、且神供直相)

正大工と権大工が儀式直後に禄をもらうのに対して、棟梁・長は庁 屋に場所を移してから禄をもらう。大工は人前で肩に掛けられると いう形で禄を受けるため、現物でなければならなかったと考えるこ とができる主11)。さらに正大工は氏神祢宜より禄を渡されるのに対し て、権大工は氏神祢宜より 1 つ位の低い氏神祝より禄を渡されると いう点でも差がつけられている。

また少なくとも正徳度以降、禄は後で米に交換されることになっ ている注 12$)$ 。後で交換される米は大工が 3 斗で棟梁・長が 2 斗と一定 である。最初にもらう禄が変わろうとも、交換される米の量は一定 であり、最初の禄は形式だけであったことがわかる。なお延宝度には、

近々木作始執行候、急々)義候間、先当日之次第・作法相談可 有之之て則此度之銀子ノ割 7 以随分質略ノ筋 $コ$ 以書記候（略）

大工・諸職人へも装束・被物等一向二停止候

とあり 注 ${ }^{13)}$ 、実質的な禄がなかったようである。また通常ならば装束 も儀式で着たものをもらっていたようである。

ここで木造始めの作法を思い出してみると、正徳度を境に大きく

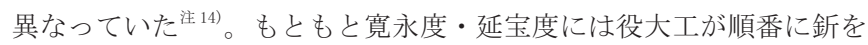
打っていた。それが正徳度以降には正大工と権大工だけが釿打ちを するものとなっていた。

以上のように、作法が変化したのに対して祝儀は実質的に変化し なかった。木造始めでは少なくとも延宝度以降、祝儀は大工と棟梁・ 長の間で形式が異なっていた主 ${ }^{15}$ )。寛永度・延宝度に役大工全員が 順に釿を打っていたこととは異なる傾向といえる。同様に、正徳度 以降棟梁が墨を打ち、大工が釿を打ち、長はそれぞれの補助を担当 していたことを考えると、棟梁と長の祝儀に差がつけられず、作法 の内容とは対応していないといえる。祝儀の形式・量は作法の内容 よりむしろ役大工の地位によるものと考えることができる。ただし、 儀式終盤において大工だけが禄をもらい、棟梁・長は儀式後に別の 場所で禄をもらうという儀式の執り行われ方とは一致している。そ のため、役大工が受ける祝儀の厚薄は、より広義には儀式の内容と 対応しているともいえる。

\section{2. 立柱}

立柱における役大工の祝儀は、地位によって差がつけられている (表 2)。寛永度に行なわれた本殿立柱の事例しかみつからず、検討す るには不充分であるが、大工と棟梁を比べると大工のほうが棟梁よ りも樽、鯛の量が多く、寸るめが加えられ、品目自体が多くなって

表 2 寛永度の本殿立柱における祝儀注 16$)$

\begin{tabular}{|l|l|l|}
\hline 職名 & 正大工のグループ & 権大工のグループ \\
\hline 大工 & 樽3つ、鯛3枚、昆布1束、するめ1連 & 樽3つ、鯛3枚、昆布1束、するめ1連 \\
棟梁 & 樽1つ、鯛2枚、昆布1束 & 樽1つ、鯛2枚、昆布1束 \\
長 & なし注1 & なし注1 \\
\hline
\end{tabular}

注 1 ただし、「制大工中」へ樽2つ、昆布 1 束、するめ 8 連

表記・単位は史料通り 
いる。また長に渡される祝儀はなく、惣大工中」として渡されている。 長だけでも 5 人いたことを考えると、大工と棟梁に比べて非常に少 なかったことがわかる。

ここで木造始めと同様に立柱の作法を思い出してみると、少なく とも正徳度以降、正大工のグループ、権大工のグループがそれぞれ

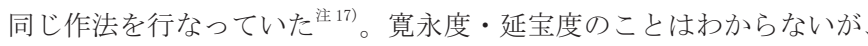
正徳度以降、長から棟梁、棟梁から大工一供物が渡され供えられて いる。また長から棟梁へ供物が渡され供えられている。

以上のように、立柱では少なくとも寛永度には大工、棟梁、長と 地位によって祝儀に厚薄があった。延宝度以降の儀式における役大 工の作法を寛永度の儀式にもあてはまるものとして祝儀の厚薄と比 べると、大工は供物を供えるだけであり、棟梁は供物を供える以外 に大工一供物を渡すという補助的な役割を担い、長は大工と棟梁の 供物を運ぶだけというまったく補助的な役割に当たっていた。この ことと祝儀の厚薄は対応しているといえ、ひいては役大工の地位と も対応しているといえる。

\section{3. 上棟}

上棟における役大工の祝儀は役大工の地位によって差がつけられ ている（次ページ表 3）。

正徳度までの本殿上棟では正大工のグループのみが祝儀を受け、 権大工のグループは祝儀を受けていないのに対して、権殿上棟では 正大工のグループは祝儀を受けず、権大工のグループのみが祝儀を 受けている。寛永度本殿上棟においては、大工と棟梁の祝儀は比較 的似ていて、大工と棟梁の間には掛銭の違いと、大工が奉幣と弓矢 をもらっているのに対して棟梁は幣と桘皇もらっているという違い があるだけである。長はとくに供物の種類が少ない。道具について も一見すると幣と桘を 3 本ずつもらい棟梁よりも多いようにみえる が、長が 3 人いることを考えると棟梁と変わりない。ただし、長だ けがもらっているものに「柱巻」と「膝突布」がある。寛永度の権 殿上棟では、このような配分は示されず、酒樽かなにかを大工、棟梁、 長がそれぞれひとりあたり 10 荷、5 荷、2.5 荷もらっている。これ は地位の順によって 2 倍の量を受けとっていることになる。

役大工の祝儀配分について次のような規定がある。延宝度造営の 場合について、当時の『日次記』には注 19)、

去寛永之度もヶ様ノ申分出入等有之云々、惣入旧記等之射、御 弓矢・御幣・諸神供等支配ノ義八何も半分ツ、二割、壱ツ分 大工、相残壱つ分 7 武ツニ配、其壱ツ分 7 棟梁、又相残分 長棟梁当分二支配申云々、縦令御幣四棒内武棒八大工、残式棒 之内一棒八棟梁、一棒八長棟梁、縦雖為何人、可支配之旨所見事、 然者此度権大工申分御弓武張頂戴之、御矢ノ分 との事、今少如何此義八御弓矢一対ツ、可然骺、且又権棟梁御 幣一棒大工一配分仕事、非沙汰之限䯘、御棟ノ幣一棒・振幣一 棒以上武棒大工一可渡之者也、勿論自余可準之

とある。このことと大工・棟梁・長の人数比から弓矢・幣・供物の配分は、

正大工 : 正棟梁 : 正長 $=6: 3: 1$

権大工 : 権棟梁 : 権長 $=4: 2: 1$

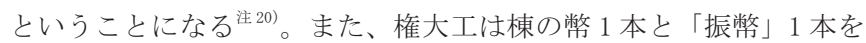
受け取ることが賀茂別雷神社によって決定している。延宝度本殿上 棟でも、幣はそれぞれ 1 本ずつもらっているが、正大工はさらに「振 幣」をもらっている。
ただし、掛銭はこのような比率で配分されていないことが多い。 寛永度および正徳度の本殿上棟の掛銭では、棟梁と長の間にも差が つけられている。しかし、延宝度のような整数倍にはなっていな い。また、安永度以降は主導する側の大工・棟梁と主導する側の長・ 補助する側の大工・棟梁・長の間で 2.5 倍の差がつけられるように なっている。配分に関する別の決まりがつくられたものと思われる。 ただし、関係する記事はみつかっていない。

弓矢の配分は確定されていないようであるが、その後本殿上棟で 起こった同様の問題から弓矢のこともわかる。『日次記』には注21)

元大工へ八御弓武張二而も可有之、然

仕、御弓一張ツ、支配仕

とあり、賀茂別雷神社としては寛永度の配分が異例のことであって、 本来大工が弓 2 張をもらっていたことを認めている注22)。そして安永 度以降の祝儀をみると大工が弓 2 挺、棟梁が矢 2 本と絃 2 筋 1 正を もらっていることから、権大工の言い分が通ったことがわかる゙ ${ }^{\text {注 } 23)}$

また、禄は大工だけが多く受けている。延宝度・正徳度・寛保度 の事例をみると、大工の祝儀は呉服 1 重と馬 1 㱜、棟梁・長は呉服 1 つと馬 1 㱜の折紙を受けている。延宝度権殿上棟の少し前の『日次 記』注 24) には権大工の祝儀は小袖 2 つと馬 1 疋、権棟梁・権長の祝儀 は小袖 1 つ馬 1 㱜となっていることから、咫服は小袖のことであり、 呉服 1 重は呉服 2 つのことであったことがわかる。

寛保度以降の本殿上棟は正大工のグループも権大工のグループも ともに祝儀を受けている。寛保度には延宝度本殿上棟でいう「給禄 折紙」のみしか記されていないが、権大工のグループにも渡される ようになっている。安永度・享和度は同様の内容であり、大工と棟 梁のもらう分も掛銭をふくめほぼ同様であるが、大工のみがもらっ ているものとして弓・声綱・奉幣があり、棟梁のみがもらっている ものとして絃と矢がある。長 3 人も均一ではなくなっている。長 a と長 $\mathrm{b}$ は同様であるが、長 $\mathrm{c}$ は比較的少なくなっている。大工・棟 梁とくらべて、樽や鯛などといった供物の種類もへり、数もへって いる。長だけがもらっているものとして槌と充木がある。一方、権 大工のグループが受ける祝儀は正大工のグループが受ける祝儀と比 べて格段に少ないが、神酒は権大工のグループだけがもらっている。 寛保度以降の権殿上棟における祝儀は記されていない。天保度の 権殿上棟には「供物頂戴之割、右割方享和二委し」などとあり、先 例によっていたことがわかる。ただし、享和度の祝儀が不明であり、 具体的なことはわからない。

安永度の権殿上棟における祝儀について権棟梁からの願書が記さ れているので、この願書を検討しておくことにする。この願書は全 体を朱で抹消してあるため、実際に行なわれたものではないと思わ れる。内容をみても延宝度などに起こった訴訟と同様、権大工への 配分と権棟梁への配分が安永度本殿上棟などと比べて異なっている。 ただし、「充木」や「鹰布」など本殿上棟で渡されている道具が記さ れていない。これは本殿上棟に再び使用するために分配されず残し ておかれたのかもしれない注25)。

ここでこれまでと同様に上棟の作法を思い出してみると、寛保度 を境に大きく変化していた注 ${ }^{26)}$ 。寛永度・延宝度には本殿上棟は正大 工のグループだけで行なわれ、権殿上棟は権大工のグループだけで 行なわれていた。それが正徳度の本殿上棟に権長が、権殿上棟に正 長が加わるようになるという段階を経て、寛保度以降になると、本 
殿上棟は、正大工のグループが主導するものの、権大工のグループ と共同で執り行うという形をとり、権殿上棟では権大工のグループ が主導するものの、正大工のグループと共同で執り行うという形を とっていた。

以上のように、寛保度に作法が変化したのと同様、祝儀について も変化がみられた。上棟では地位によって祝儀に厚薄があるだけ でなく、一方のグループだけが祝儀をもらう場合と他方のグループ よりも祝儀が多い場合があった。寛永度から正徳度までは本殿上棟 では正大工のグループだけが地位の順に多く祝儀をもらい、権殿上
棟では権大工のグループだけが地位の順に多く祝儀をもらっていた。 寛保度以降は、本殿上棟において権大工のグループも祝儀をもらっ ていた。寛保度は禄以外の祝儀が不明であるが、安永度・享和度・ 天保度の本殿上棟では正大工のグループのほうが祝儀が多く、同一 グループ内で比べると地位の順で祝儀に厚薄があった。また、大工 だけがもらう祝儀、棟梁だけがもらう祝儀、長だけがもらう视儀 があった。寛保度以降本殿上棟に権大工のグループが祝儀をもらう ことと、延宝度と安永度以降に特定の役職にあるものが特定の道具 をもらうということは、儀式の作法と密接に関係しているといえる。

表 3 上棟の祝儀注 18$)$

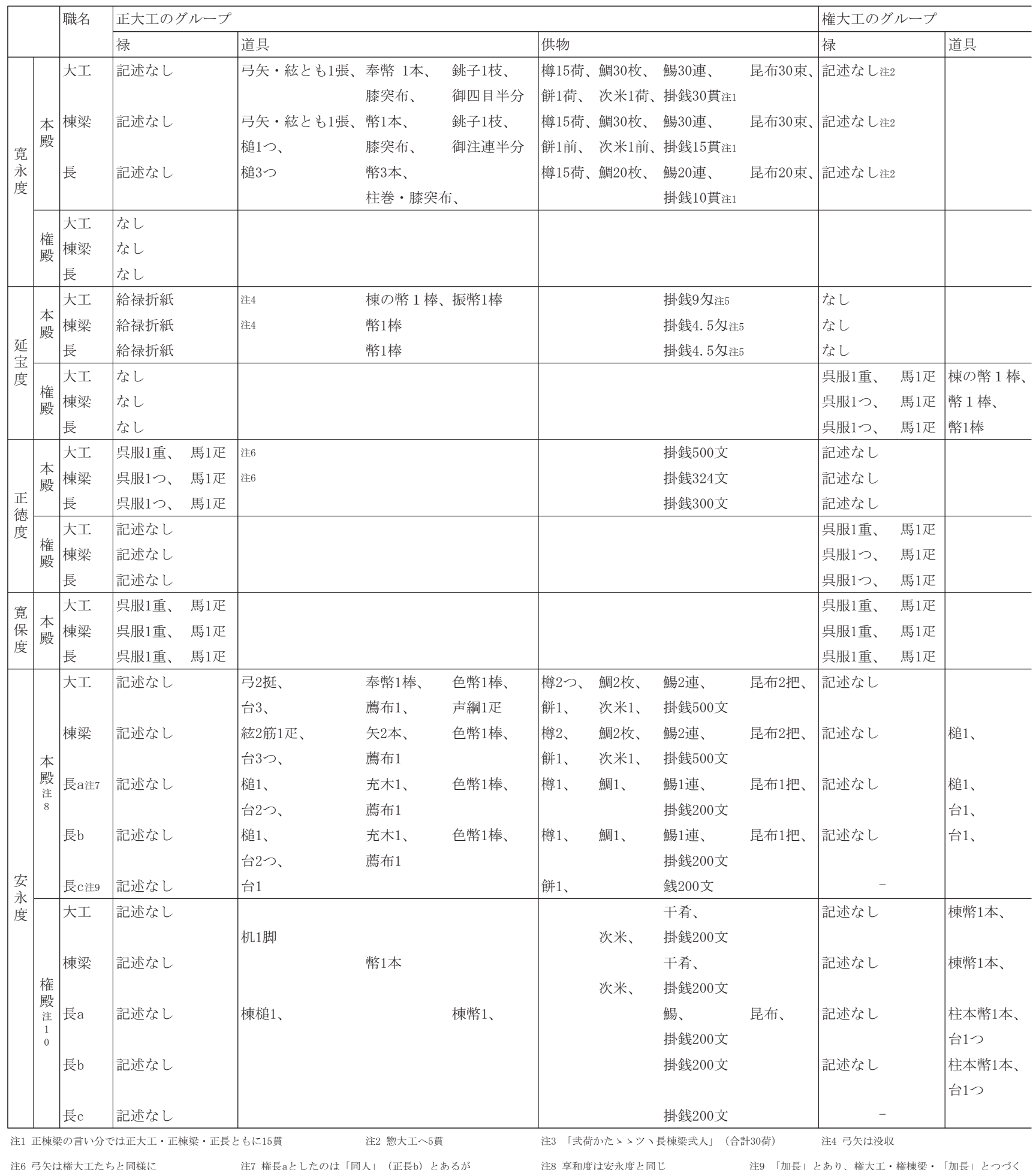


ただし、棟で神酒を供えるのは正棟梁であったが、もらうのは権棟 梁であった。

\section{4. 玉橋渡始め}

玉橋渡始めにおける役大工の祝儀には地位の違いによって差がつ けられている（次ページ表 4)。寛保度には平樽と昆布にのみ違いが あり、大工は奉幣を、棟梁は槌と鳴らし木を、長は飾幣をそれぞれ 独占的にもらっている。安永度・享和度・天保度・文久度は祝儀の 内容は全く同じで、寛保度とは少し異なっている。昆布は同じ量に なり、干鱈は大工だけが多くなっている。さらに掛銭は寛保度には

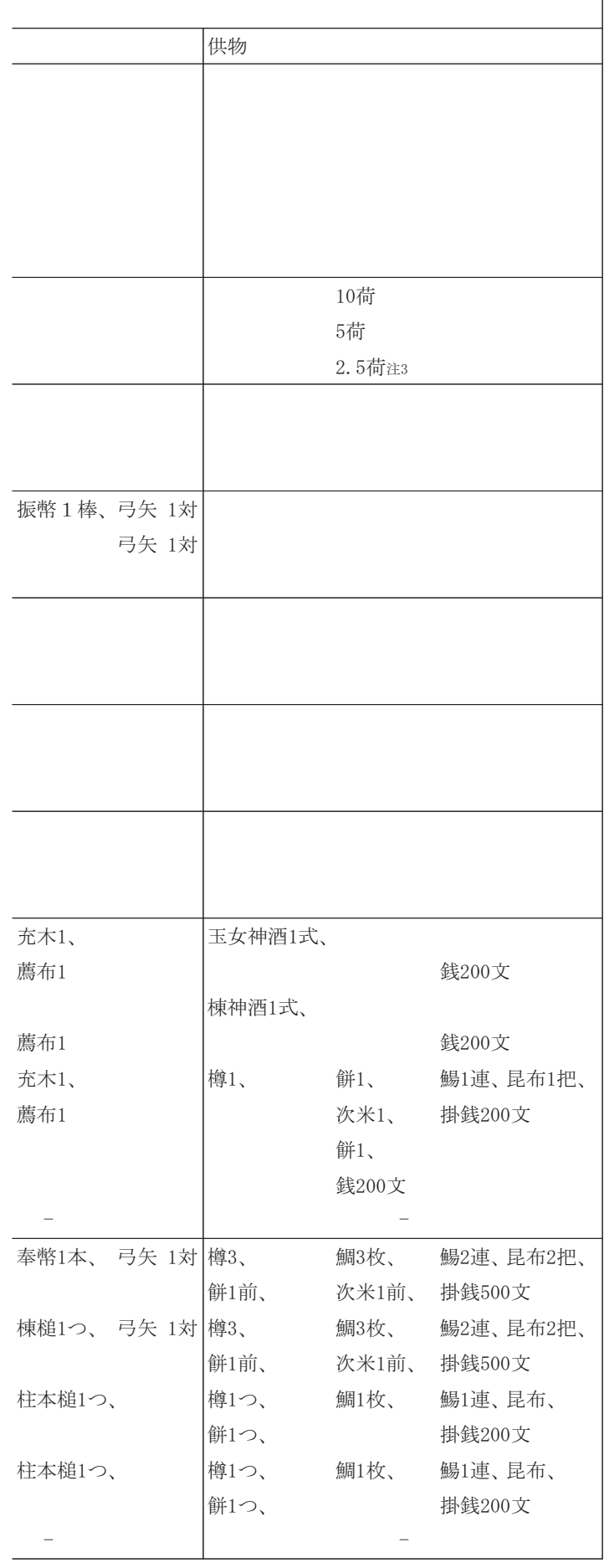

注 5 正徳度の記事より。ただし、日付けは権殿の日付。長は 3 人分 注10 権棟梁の願書、抹消されている
大工と棟梁で同じだけ受けとっていたが、安永度以降 8 文だけ大工 のほうが多くなり注28)、差がつけられるようになった。また長の掛銭 は安永度以降、寛保度よりも20 文上がっている。

ここでやはりこれまでと同様に玉橋渡始めの作法を思い出してみ ると、正大工のグループと権大工のグループが順に作法を執り行っ ていた注 ${ }^{29)}$ 。まず、長、正棟梁を経て渡された幣を正大工が振り、そ れに合わせて長から渡された桘を正棟梁が打つ。つづいて長、権棟 梁を経て渡された幣を権大工が振り、それに合わせて長から渡され た槌を権棟梁が打つ。この儀式は寛保度と安永度以降で槌を打つ場 所が橋の両詰から東詰のみになったが、作法自体に変化はなかった。

以上のように、寛保度以降、作法がほぼ変化しなかったのと同様に、 祝儀もほぼ変化しなかった。玉橋渡始めでは役大工の地位によって 祝儀にわずかながら差がつけられている一方で、正大工のグループ と権大工のグループには差がつけられていない。このことは寛保度 と安永度以降で細かい違いがあるものの基本的には同様である。ま た幣など役職特有の祝儀は儀式で担当した役割で使用したものであ った。これらのことから玉橋渡始めの祝儀は、儀式の作法が寛保度 以降わずかな変更しかくわえられなかったことと一致し、作法内容 とも一致するといえる。

\section{3. おわりに}

本稿では江戸時代に賀茂別雷神社で行なわれた幕府による造営に おいて執り行われた儀式における役大工の祝儀を検討した。

祝儀の違いは、大工・棟梁・長という地位によると考えられた。 とくに上棟では延宝度に地位による分配方法が決められている。安 永度以降になると、別の方法が決められたようである。儀式を主導 する側の大工と棟梁の祝儀は差がほぼなくなるが、長と儀式を補助 する側の大工・棟梁はより少ない祝儀であった。また、木造始めで は江戸時代を通して棟梁と長の祝儀が等しかったのに対して、大工 の祝儀だけが多かった。同様に、玉橋渡始めでも安永度にわずかで あるが大工の视儀が棟梁より多く設定されている。これらのことは 大工、棟梁、長がという分類が儀式における役割分担以上のもので あったことを示しているといえる。また棟梁の祝儀は、大工の祝儀 に近い儀式と長の祝儀に近い儀式があった。このことは長から派生 したであろう棟梁について考えていくうえで参考になると思われる。

さらに、祝儀の違いは儀式における役割の違いにもよっていると 考えることができた。上棟・玉橋渡始めでは儀式で使う道具が実際 にその道具を儀式のなかで使った建築工匠に渡されている。また寛 保度以降の上棟でみられた主導するグループと補助するグループに 大きな違いは、正徳度以前の上棟や、正大工・権大工の各グループ と本殿・権殿の組み合わせと対応しているといえる。

注

注 1) 中西大輔 ・ 日向進「賀茂別雷神社役大工と大徳寺」『日本建築学会大会学 術講演梗概集 (東北)』2009 年 8 月、同「賀茂別雷神社役大工の編成」『日本 建築学会大会学術講演梗概集 (関東)』2011年 8 月

注 2）谷直樹・植松清志・大上直樹「近世における上賀茂神社の造営と大工に ついて」『平成 18 年度日本建築学会近畿支部研究報告集』2006 年 5 月、谷直 樹「遷宮と造替」大山喬平監修、石川登志雄・宇野日出生・地主智彦編『上 賀茂のもり・やしろ・まつり』思文閣出版、2006 年 6 月、前掲注 1 「賀茂別 雷神社役大工と大徳寺」

注 3) 中西大輔 - 日向進「賀茂別雷神社の役大工と儀式について」『日本建築学 会計画系論文集』第 77 巻第 671 号、 2012 年 1 月 
表 4 玉橋渡始めの祝(義注 27)

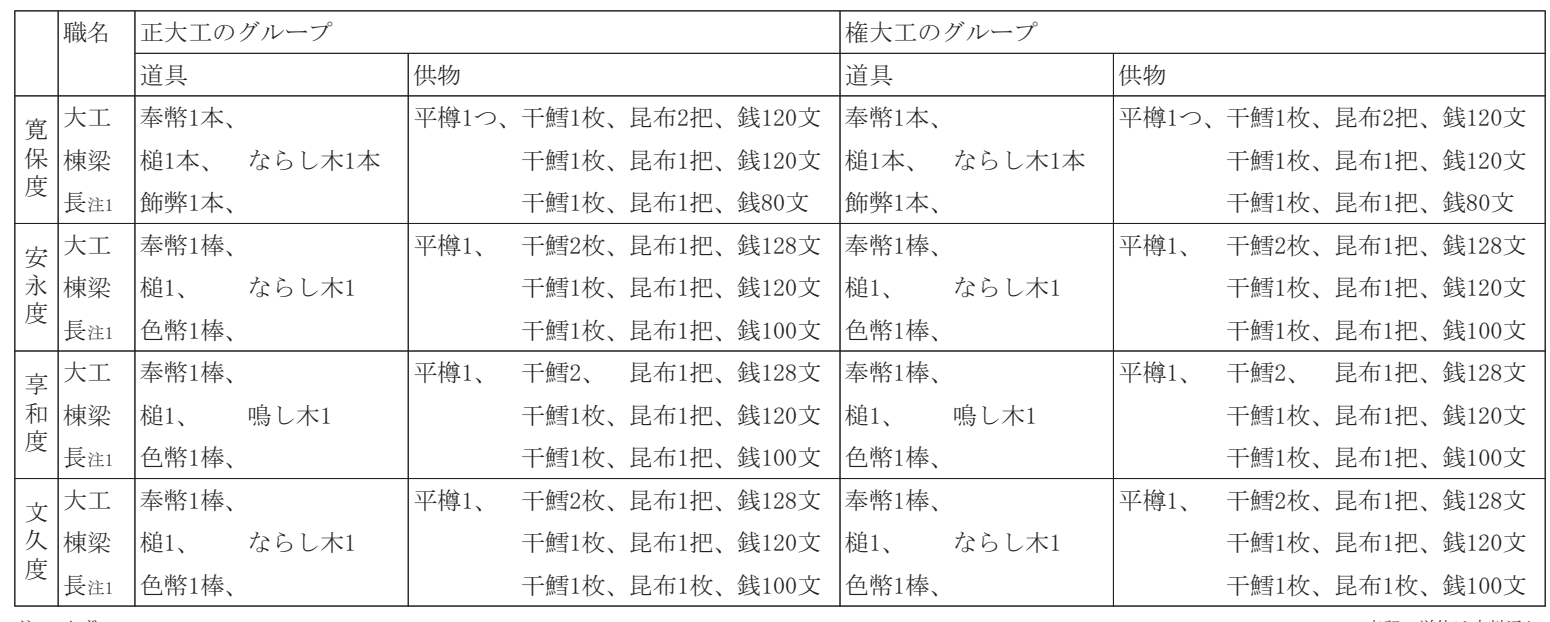

注 4)『賀茂別雷神社文書』(賀茂別雷神社蔵)

注 5)『賀茂別雷神社文書』(賀茂別雷神社蔵)。( ）内の数字は『賀茂別雷神 社文書目録』(京都府教育委員会、2003 年) と対応寸る。以下でとくに断ら ない限り、『賀茂別雷神社文書』を引用している。

注 6)『賀茂別雷神社文書』(賀茂別雷神社蔵)。必要に応じて延宝度以外の造営 でも参照する。なお、本稿で用いた『日次記』は東京大学史料編纂所による。 注 7) 寬永度については『寛永造替遷宮記 上』(III-23-1)、、寛永造営遷宮記』(IV -A-43）寛永 4 年（1627）10月 1 日条。延宝度については『日次記』延宝 7 年（1679） 1 月 27 日条。正徳度については『造営日記』（III-21-2）宝永 7 年（1710） 12 月 23 日条、『日次記』同日条。寛保度については『宽保御造営 抜書 全（従元文五年十二月八日）』（III-23-4）寛保元年（1741）1月 23 日 条、『寛保遷宮私記（自元文六年正月至寛保元年十二月）』(III-23-6) 同日条 安永度については『御造営雑記』（III-21-21）安永 6 年（1777）２月４日条。 享和度については『御造営日記（自五月一日至十五日）』(III-23-17) 享和元 年（1801）5月 14 日条、同 15 日条。天保度については『三御造営日記』(III -22-13）天保 5 年（1834）9 月 9 日条、同 11 日条。文久度については『御造 営仮日記七』(III-22-25) 文久 3 年 (1863) 5 月 27 日条。

注 8) 河鯺実英『日本服飾史辞典』東京堂出版、昭和 44 年

注 9) 新村出『広辞苑 第六版』(岩波書店、2008 年 1 月) に上れば、「疋」は 1 疋で布帛 2 反をあらわし、「反」は成人 1 人前の衣料に相当する量をあら わすという。したがって、材料としては棟梁・長のほうが多くなってしまう。 しかし少なくとも後述のように、大工と棟梁・長とは祝儀をもらう場所と方 法が異なる。そのため、大工の小袖「1つ」はその方法によっている。

注 10) 引用は『御造営雑記』(III-21-21) 安永 6 年 2 月 4 日条上り。延宝度か ら文久度の木造始めにおいても類似の記述がある。

注 11）『日次記』延宝 7 年 1 月 27 日条には、儀式のなかで「今日為祝義折紙 正・権大工両人下給候告年公形県服リツ充」と記され、折紙だけが渡されている。 注 12）『日次記』宝永 7 年 12 月 23 日条には「寛永二八被物小袖給之、延宝二 八形八カリノ折芯也、此度八如此後料物二引替可被下之評也」とある。文久 度造営などには「下行」として記されている。

注 13)『日次記』延宝 7 年 1 月 20 日条。先の延宝 7 年 1 月 20 日条からもわかる。 寛保度にも、『寛保御造営抜書 全（従元文五年十二月八日）』(III-23-4) 寛 保元年 1 月 23 日条に、「禄之事、延宝八素目録、正徳八正・権大工江金襴八 尺宛、正棟梁以下江折帋・絹壱疋ツ、(略)」とある。

注 14）前掲注 3 「賀茂別雷神社の役大工と儀式について」。正徳度については『日 次記』の次第を参照した。

注 15) なお、『宽永造替遷宮記 上』（III-23-1)、『寛永造営遷宮記』（IV - A 43）寛永 4 年（1627）10月 1 日条によれば、儀式後、庁屋で催される「無飯饗」 においても大工と棟梁・長との間でつぎのような差がつけられている。大工 には「三ツ杯」がつくが、棟梁・長にはつかない。また大工・棟梁には神社 の役人から酒が注がれている。

注 16)『寛永造替遷宮記 上』（III-23-1)、『寛永造営遷宮記』（IV - A-43）寛永 5 年 8 月 22 日条

注 17）前掲注 3 「賀茂別雷神社の役大工と儀式について」

注 18) 寛永度については『寛永造替遷宮記 上』(III-23-1)、『寛永造営遷宮記』 (IV-A-43) 寛永 5 年 3 月 26 日条、『日次記』正徳元年 12 月 7 日条。延宝度 については『日次記』延宝 7 年 6 月 2 日条、同 6 日条、同 8 月 7 日条、正徳
元年 12 月 7 日条。正徳度については『宝永八年辛卯御造営日記』(III - 21-3) 正徳元年 6 月 23 日条、『日次記』正徳元年 6 月 23 日条、同年 12 月 7 日条、『正 徳元年辛卯年御造営日記』(III-21-4) 正徳元年 9 月 5 日条、『日次記』同 9 月 5 日条、同 12 月 7 日条。寛保度については『寛保御造営拔書 全（従元 文五年十二月八日)』(III-23-4) 寬保元年 8 月 21 日条。安永度については『御 造営雑記』(III-21-25) 安永 6 年 6 月 27 日条。享和度については『十四御造 営日記』(III-22-7) 享和元年 10 月 24 日条。安永度権殿上棟の願書について は『御造営日記』(III-21-23) 安永 6 年 4 月 24 日条。

なお、安永度・享和度には、このほかに「声掛」、「随身」、「幣取次」、「正 大工詰合」という役を務める建築工匠たちに祝儀が渡されている。配分は次 のとおり。声掛「樽 1 、鰑 1 、昆布 1 、掛銭 150 文、餅 1 、染米 1 、台 1 、薦布 1 、 随身「鯛 1 、染米 1 、掛銭 150 文、台 1 、鹰布 1 、幣取次「銭 100 文」、正大 工詰合「銭 50 文」。

注 19）延宝 7 年 6 月 6 日条。これは権大工と権棟梁の間で配分について訴訟が 起こったことによる。引用部分前半には、権大工と権棟梁が「双方共二旧記 口伝来之旨申上」ていることが書かれている。それによると、権棟梁の「指図」 による配分に対して「前々より其法式有之」、「少分之義雖有之候、前々より ノ法、未代迄之義候間、右之通、相渡申様二被仰渡可被下候」として権大工 が挀訟を起こしたのである。なお、権大工は「御弓矢・御張ノ内、御弓木式本、 御幣三本并奉幣一本以上四本之内、奉幣と御棟之幣一本と二本」を受け取る はずとしたのに対し、権棟梁は「御弓・御張之内一張分、権大工、御幣以上 四本之内壱棒、権大工、其外樽·肴諸事支配ノ身、前々よりノ法二候」とした。 注 20)この方法は供物の配分にも使われているという。延宝度から寛保度まで は、ほかの供物をもらったことは書かれていない。寛永度、安永度以降にも 供物をもらっていることから考えてもらっていたと思われる。しかし、配分 の比率を確認することはできない。

注 21)『日次記』延宝 7 年 8 月 7 日条

注 22）ただし延宝度には、本来弓矢ももらうはずであったが、賀茂別雷神社に 没収されている。これは『日次記』正徳元年 12 月 7 日条によれば、延宝度 の上棟で正大工と正棟梁が弓矢配分のことでもめたことによる。なお正徳度 には、弓矢の配分も権大工のグループと同様とある。そのため、権大工の祝 儀には弓矢などが省略されているだけとわかる。そのため、やはり書かれて いない供物もあり、省略されていただけとみることができる。

注 23）ただし後述するように、安永度にも権棟梁から同様の願書が賀茂別雷神 社に提出されているが、却下されているようである。

注 24)『日次記』延宝 7 年 5 月 27 日条

注 25）「声網」も記されていないが、これは本殿のみにあるものである（前掲 注 3 「賀茂別雷神社の役大工と儀式について」)。

注 26）前掲注 3 「賀茂別雷神社の役大工と儀式について」

注 27) 寬保度については『寬保御造営抜書 全（従元文五年十二月八日）』(III -23-4) 4 月 25 日条。安永度については『御造営日記』(III - 21-23) 安永 6 年 4 月 9 日条。享和度については『十五御造営日記』(III-22-8) 享和元年 11 月 7 日条。文久度については『御造営仮日記十三』(III-22-32) 文久 3 年 12 月 20 日条。

注 28）安永度の祝儀配分については 120 文の上から「八」が書加えられている。 注 29）前掲注 3 「賀茂別雷神社の役大工と儀式について」

（2011年11月10日原稿受理，2012年 1 月11日採用決定） 